\title{
NOTES ON ELLEANTHUS MUSCICOLA (ORCHIDACEAE) AND DESCRIPTION OF A NEW EPILYNA SPECIES FROM PANAMA
}

\author{
Marta KolanowsKa $^{1}$ \& Dariusz L. SzlachetKo
}

\begin{abstract}
The generic affinity of Elleanthus muscicola Schltr. is clarified and a new combination within Epilyna Schltr. is proposed. The differences between Epilyna and morphologically similar genera are discussed. Epilyna trilobata Kolan. \& Szlach., a new species so far known only from Panama, is described, illustrated and placed within a key to identification of all Epilyna species.
\end{abstract}

Key words: Elleanthus, Epidendrum, Epilyna, Panama, taxonomy

Marta Kolanowska \& Dariusz L. Szlachetko, Department of Plant Taxonomy and Nature Conservation, University of Gdańsk, Wita Stwosza 59,80-308 Gdańsk, Poland; e-mail: martakolanowska@wp.pl

\section{INTRODUCTION}

The Neotropical genus Epilyna was proposed by Schlechter (1918) based on E. jimenezii Schltr. The author found it similar in habit to Epidendrum L. but different in its flower structure, which resembles Elleanthus C. Presl. From the latter genus Epilyna is easily distinguished by its leaves, which are conduplicate, obliquely bidentate and minutely mucronate at the apex. The leaves of Elleanthus s.str. are always plicate, thin or relatively stiff, and acute to acuminate. Unlike Epidendrum, the flabellate lip of Epilyna is not fused with the gynostemium and at the base is furnished with subglobose corpuscules. The two genera are easily separable by gynostemium structure. The gynostemium of Epidendrum is slender, elongate, erect or slightly arched, and finely swollen towards the apex. Usually four pollinia are produced in the anther. They are equal or unequal in size and form, obliquely ellipsoid, ovoid to clavate, laterally compressed, and rather hard. The prominent, granular and sticky caudiculae are attached to each pair of pollinia. The apical clinandrium is usually spacious, occasionally reduced, and entire or with fringed margins. The stigma is bilobed; both lobes are connate and sticky. The rostellum is erect, shelf-like, and

\footnotetext{
1 Corresponding author
}

truncate. The single viscidium is usually longer than the caudiculae, oblong to ovoid, dorsiventrally compressed, and detachable. The rostellum remnant is more or less incised. In Epilyna the gynostemium is erect and rather short. The eight pollinia are rather unequal in size and form, ellipsoid to obovoid, slightly flattened laterally, and joined together by small, inconspicuous, sticky cauciculae. The apical clinandrium is prominent and rather spacious but entire. The stigma is rather large, transversely elliptic, and deeply concave. The truncate rostellum is bent forwards. Neither a viscidium nor tegula are produced (Szlachetko \& Margońska 2002).

The generic distinction of Epilyna was discussed for many years. Schweinfurth (1937) proposed to include the only species of the genus known at that time in Elleanthus. This concept was not accepted by Dodson, who described two other species of Epilyna (Dodson 1989, 1994). The results of recent molecular studies indicated that Epilyna is sister to Elleanthus (Rothacker 2007; Neubig et al. 2011) and currently the genus is widely accepted.

There is, however, one species whose generic affiliation is not resolved: Elleanthus muscicola. It was described by Schlechter (1923) just five 
years after establishment of the genus Epilyna. The author placed it in Elleanthus but noted its similarity to Epilyna. While the inflorescence of Elleanthus muscicola is characterized by the Elleanthus-like arrangement (obscurely fractiflex raceme with imbricating floral bracts), its conduplicate leaves and subglobose calli connected to the lip margins resembles those of Epilyna. Dudek and Szlachetko (2010) considered Epilyna muscicola to be conspecific with $E$. jimenezii Schltr., but the two species differ significantly in their inflorescence structure, especially in floral bract size. While in E. jimenezii the inflorescence is somewhat elongated and its leaves become smaller to gradually form triangular-ovate floral bracts which are somewhat spaced, the inflorescence of E. muscicola is very short and its bracts are cucullate, sphacelate, and imbricating. Therefore we propose to treat those taxa as separate species of Epilyna and the new combination is given in this paper.

Our recent studies of Panamanian orchids revealed the existence of a distinctive Epilyna species related to E. muscicola. It is described here as new and placed within a key to identification of Epilyna species.

\section{NeW COMBINATION}

Epilyna muscicola (Schltr.) Kolan. \& Szlach., comb. nov.

BASIONYM: Elleanthus muscicola Schltr., Fedde Rep. Sp. Nov. Beih. 19: 10. 1923.

\section{DESCRIPTION OF A NEW SPECIES}

Epilyna trilobata Kolan. \& Szlach., sp. nov. Figs $1 \& 2$

Species resembling Epilyna muscicola (Schltr.) Kolan. \& Szlach., but with entire petals, a trilobulate lip apex, and five somewhat thickened veins running from the lip base up to the lip apical lobe.

Holotype: PANAMA, Prov. Panamá, La Eneida, region of Cerro Jefe. 25 Jun. 1969. Dressler 3640 (MO; ISOTYPE: PMA; UGDA - drawing of the type).
Small caespitose plants, 6-10 cm tall. Stems slender, leafy. Leaves coriaceous, 11-13 mm long and 5-6 mm wide, oblong-ovate, apex bilobulate with a minute apicule. Inflorescence 10-15 mm long, a slightly fractiflex raceme, 5-12-flowered. Ovary $3 \mathrm{~mm}$ long. Floral bracts up to $c a 10 \mathrm{~mm}$ long, oblong-ovate to ovate, imbricating, scarious, sparsely furfuraceous. Flowers white, sepals with some furfuraceous dark hairs. Dorsal sepal 3.2$3.5 \mathrm{~mm}$ long and $1.3-1.5 \mathrm{~mm}$ wide, ovate, acute, 1-nerved. Lateral sepals $c a 3.5 \mathrm{~mm}$ long and $1.4 \mathrm{~mm}$ wide, ovate-lanceolate, acute, 1-nerved. Petals $3.2-3.5 \mathrm{~mm}$ long and $0.5-0.9 \mathrm{~mm}$ wide, ligulate-oblanceolate, obtuse. Lip 3.0-4.5 mm long and 3.0-3.2 mm wide, 5-9-nerved, 3 or 5 middle veins somewhat thickened, lamina trilobulate
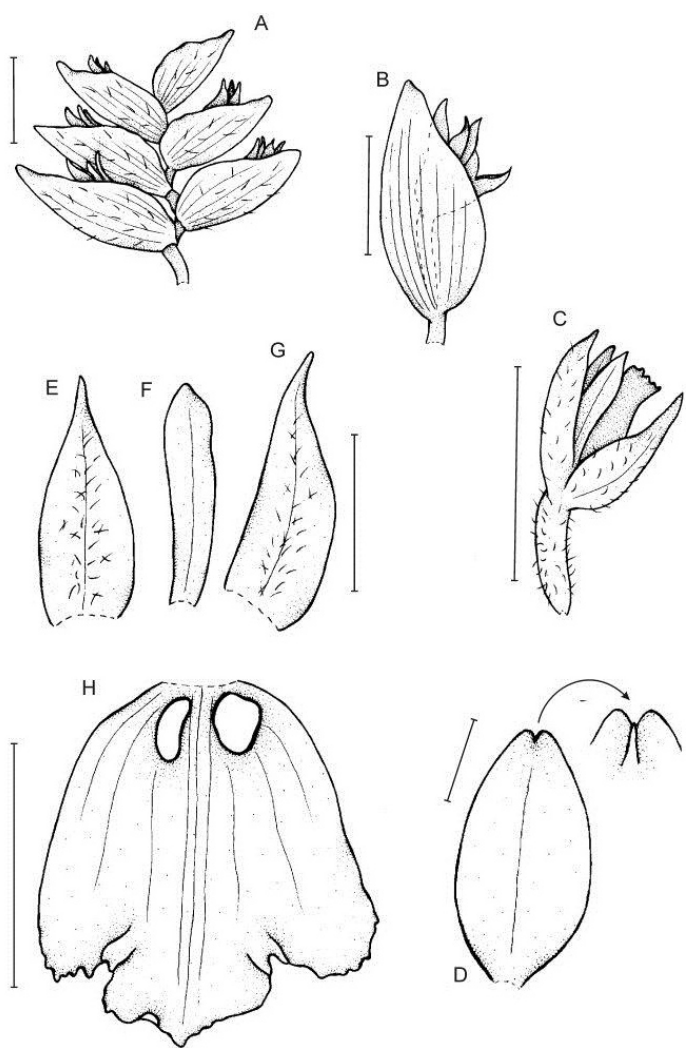

Fig. 1. Epilyna trilobata Kolan. \& Szlach., sp. nov. A - inflorescence, $\mathrm{B}$ - floral bract and flower, $\mathrm{C}$ - flower, D - leaf and leaf apex detail, E - dorsal sepal, F - petal, G - lateral sepal, $\mathrm{H}$ - lip (drawn by Natalia Olędrzyńska from holotype). Scale bars: $A-D=5 \mathrm{~mm}$; E \& $\mathrm{H}=2 \mathrm{~mm}$. 
A

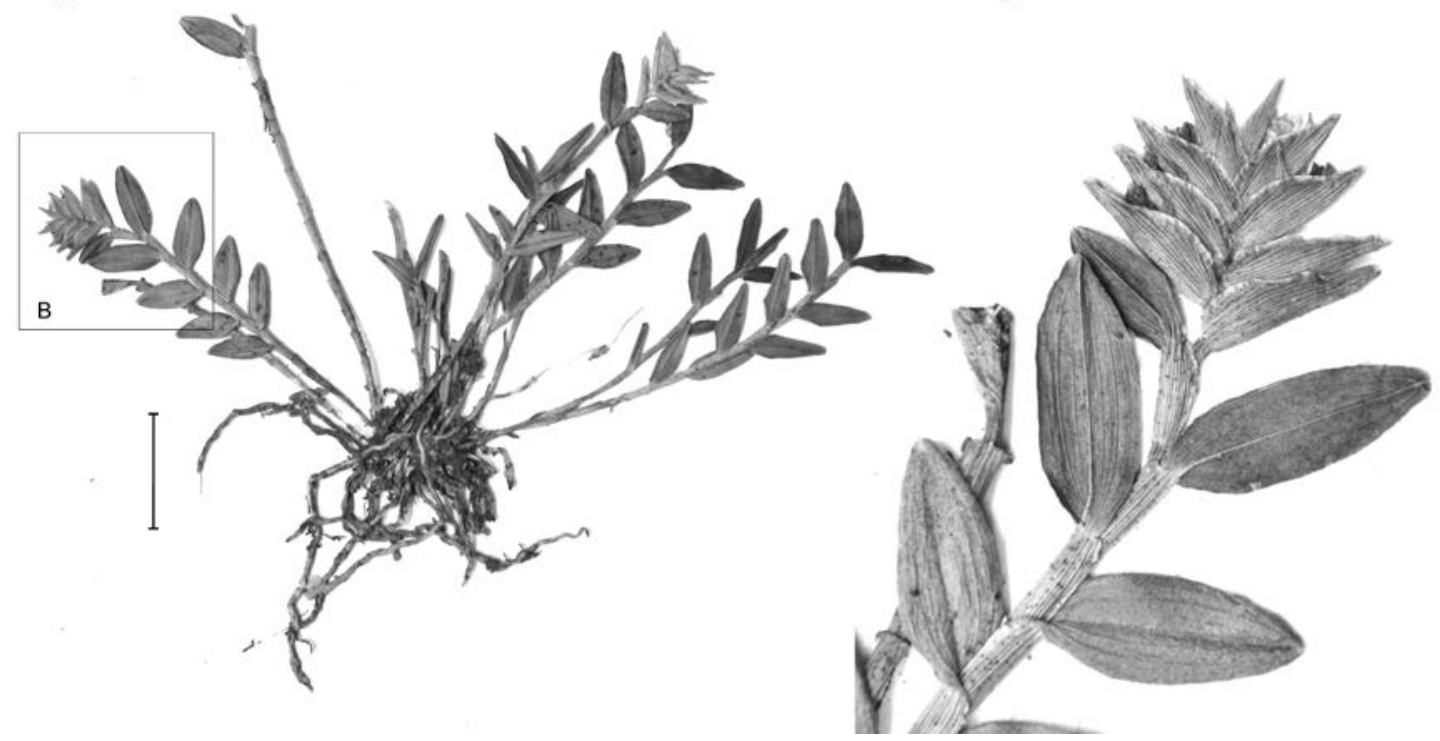

Fig. 2. Epilyna trilobata Kolan. \& Szlach., sp. nov. A - habit, B - inflorescence closeup (isotype; PMA). Scale bar $=2 \mathrm{~cm}$.

in apical part; lateral lobes oblong-ovate; apical lobule transversely elliptic, apiculate; apical margins of lobes minutely denticulate; disc in basal part with two subglobose, separated calli. Gynostemium 1.5-2.3 mm long.

EтyмоLogy. In reference to the trilobulate lip apical part.

Distribution AND ECOlOGy. So far the species is known exclusively from the type locality. It grows in tropical humid forest at elevation below $1000 \mathrm{~m}$ a.s.l. It flowers in June.

Conservation notes. While the species is known exclusively from one locality, the site of its occurrence is part of Chagrés National Park so its habitat is not endangered by anthropopression.

Notes. The species is undoubtedly related to E. muscicola, from which it is easily distinguished by the trilobulate lip apical part (vs lip apex truncate) and entire petals (vs petals crenulate-undulate apically). Moreover, the lip disc of E. trilobata is ornamented with 3-5 somewhat thickened veins running from the lip base up to the lip apical lobe.

\section{KeY TO THE SPECIES OF EPILYNA}

1. Inflorescence abbreviated, floral bracts imbricating ......................... 2

1* Inflorescence elongated, floral bracts somewhat spaced ...................... 3

2. Lip apex truncate $\ldots \ldots \ldots \ldots \ldots \ldots \ldots$ .. Epilyna muscicola (Schltr.) Kolan. \& Szlach.

2. Lip apex trilobulate . . . . . . . . . . . . . . Epilyna trilobata Kolan. \& Szlach.

3. Lip apical margin erose. . Epilyna embreei Dodson 3. Lip apical margin lacerate ............ 4 4. Lip with four subglobose calli in basal part .... ............... Epilyna hirtzii Dodson

4. Lip with two subglobose calli in basal part .... Epilyna jimenezii Schltr.

ACKNOwLEDGEMENTs. We thank the Curators and staff of MO and PMA for their kind hospitality and assistance during visits, the anonymous reviewers for valuable suggestions on the manuscript, and Natalia Olędrzyńska for preparing the illustration. The research described here was supported by the Polish Ministry of Science and Higher Education (grant no. 8124/B/ PO1/2011/40). 


\section{REFERENCES}

Dodson C. H. 1989. Epilyna hirtzii. Icon. Pl. Trop. 2(5): pl. 493.

Dodson C. H. 1994. New orchid species and combinations from Ecuador 2. Orquideologia 19(2): 123-149.

Dudek M. \& Szlachetko D. L. 2010. New combinations in subtribe Elleanthinae (Orchidaceae, Epidendroideae). Richardiana 11: 1-12.

Neubig K. M., Whitten W. M., Blanco M. A., Endara L., Williams N. H. \& Koehler S. 2011. Preliminary molecular phylogenetics of Sobralia and relatives (Orchidaceae: Sobralieae). Lankesteriana 11: 307-317.

Rothacker E. P. 2007. The primitive Epidendroideae (Orchi- daceae): phylogeny, character evolution and the systematics of Psilochilus (Triphoreae). PhD thesis, Graduate School of the Ohio State University, Columbus. https://etd. ohiolink.edu/rws_etd/document/get/osu1181830674/inline

Schlechter R. 1918. Kritische Aufzaehlung der bisher aus Zentral-Amerika bekanntgewordenen Orchideen. Beih. Bot. Centralbl., Abt. 2 36: 321-520.

SCHLECHTER R. 1923. Beitraege zur Orchideenkunde von Zentralamerika, II. Additamenta ad Orchideologiam Costaricensem, I. Orchidaceae, Amparoanae. Repert. Spec. Nov. Regni Veg. Beih. 19: 13-75.

Schweinfurth C. 1937. Nomenclatorial notes V. Bot. Mus. Lealf. Harv. Univ. 5: 38-40.

SzlachetKo D. L. \& MargońsKa H. B. 2002. Gynostemia Orchidalim II. Acta Bot. Fenn. 173: 1-275.

Received 4 December 2013 